\title{
ENVIRONMENTAL ETHICS AND RESPONSIBILITY
}

\author{
ÉTICA AMBIENTAL E RESPONSABILIDADE
}

\author{
LUIZ PAULO ROUANET ${ }^{1}$ \\ (Universidade Federal de São João del-rei, Brasil)
}

\begin{abstract}
This paper resumes a previous discussion on Environmental Ethics and Irreversibility, which was presented in 2005. There I first faced the problem. Now I would like to reevaluate the issue. Was my paper "catastrophist"? Or was it, instead, realistic? Which are today the main issues confronting Environmental Ethics? Plainly speaking, what can we really do? These are some of the questions I would like to bring in to the debate with my colleagues and the public. In other words, instead of focusing in the aspect of "irreversibility", I prefer here to focus on the "responsibility" of agents and institutions. It rescues the so-called "Principle of Responsibility", by Hans Jonas. There is also some debate with Karl-Otto Apel and Habermas. If, on one hand, there are irreversible damages to nature, as the extinction of species and even of natural locations, as rivers and other natural accidents, there are, on the other hand, many actions that can and must be taken in order to preserve or deter the grave consequences of the environmental degradation. In this paper, I try to discuss some of the problems and propose some solutions, but the more important thing is to call everyone - individuals, groups, or institutions to responsibility face the Earth, the Human and not-human beings, and mainly the future generations.
\end{abstract}

Keywords: Environmental Ethics. Global Ethics. Responsibility. Irreversibility.

\begin{abstract}
“Oui, mais il faut parier. Cela n'est pas volontaire, vous êtes embarqués. Lequel prendrez-vous donc? (...). Estimons ces deux cas: si vous gagnez vous gagnez tout, et si vous perdez vous ne perdez rien: gagez donc, qu'il est sans hésiter'. (Pascal 1963, p. 550).
\end{abstract}

\section{Introduction}

When I first reflected on environmental issues, or more specifically, on Environmental Ethics (Rouanet 2005), climate changes was not so evident and widespread as today. There were already many signals of it, but the discussion was restricted mainly to natural scientists. Even inside the scientific community there were some scholars who were skeptical about the accuracy and extent of what they called the "catastrophic" view.

Today I think that almost everyone agrees that we are really facing a scenario of radical climate and environmental change. So, in this paper, I will take for granted the reality of climate changes. My questions, then, are now different. I ask, firstly, (I) what are the main changes and their extension? I cannot tackle issue on a global level, and so I will restrain 
myself to Brazil. Secondly, (II) I will evaluate what are the main ethical questions related to these environmental issues. Thirdly, (III) I will think about what Institutions and people can really do regarding environmental issues today. My conclusions will bring more questions than answers, and I hope to hear what my fellow researchers and the public have to say about that same subject.

\section{Diagnosis}

Brazil is one of the NICs (Newly Industrialized Countries), countries of recent development which include Russia, India and China, among others. In this condition, it aims to grow, even at the cost of increasing pollution. Still, the developing countries emissions of greenhouse gases are less significant than those of developed countries emissions. The United States alone "produces about 25 percent of the global emissions" (Watson 2005, p. 382). But this is by now well-known data. What are the main environmental issues facing Brazil today?

According to the IPCC $4^{\text {th }}$ Assessment Report, some of the main issues are:

In northeast Brazil semi-arid and arid areas will suffer a decrease of water resources due to climate change $[3.4,3.7]$. Semi- arid vegetation is likely to be replaced by arid-land vegetation. In tropical forests, species extinctions are likely [13.4]

Computed groundwater recharge decreases dramatically by more than $70 \%$ in north-eastern Brazil (reference climate normal 1961-1990 and the 2050s) [3.4.2.].

Increases in rainfall in southeast Brazil have had impacts on land use, crop yields and have increased flood frequency and intensity [TS4.2].

In the future, sea level rise, weather and climatic variability and extremes modified by global warming are very likely to have impacts on mangroves [13.4.4].

$38-45 \%$ of the plants in the Cerrado (Central Brazil savannas) committed to extinction with temperature increase of $1.7^{\circ} \mathrm{C}$ above pre- industrial levels [Table 4.1]. ${ }^{2}$

Specifically in the Amazon region:

Highly unusual extreme weather events were reported, such as Amazon drought in 2005 [TS4.2].

Potential increases in drought conditions have been quantitatively projected during the critical growing phase, due to increasing summer temperatures and precipitation declines [4.4.5]

In non-fragmented Amazon forests, direct effects of $\mathrm{CO} 2$ on photosynthesis, as well as faster forest turnover rates, may have caused a substantial increase in density of lianas over the last 2 decades [1.3.5.5].

Conversion of natural vegetation to agricultural land drives climate change by altering regional albedo and latent heat flux, causing additional summer warming in key regions in Amazon region [4.4.1]

Major loss of Amazon rainforest with large losses of biodiversity with $2.0-3.0^{\circ} \mathrm{C}$ above pre-industrial levels[Table 4.1]

Increases in temperature and decreases in soil water would lead to replacement of tropical forest by savanna in eastern Amazonia. [13.4] 
Well, I think that this data is sufficient to demonstrate the reality of climate change in Brazil. $^{3}$ I would now like to discuss some of the possible causes, on a level of institutional and individual behavior, in this scenario.

On the institutional level, first, we have, for some decades, with the increasing of this attitude in the last decade or so, policies that promote industrial and urban growth, but with an emphasis on non-sustainable activities, like automobile production, extraction of the "presalt" oil (i.e., an oil which is deep inside the ocean, with high monetary and environmental costs), constructions of hydroelectric power stations, with a high environmental impact, and even the deviation of a major river (Sao Francisco), a costly and risky project.

More sustainable projects, like wind stations and non-fossil fuels, ethanol made by sugar factories etc. have been discontinued or not fostered. In sum, it is my opinion that Brazilian government is not committed to a reduction of greenhouse gas emissions and other environment issues. Its industrial and urban policies are made in narrow terms, focusing more on immediate political results than on future generations' well-being.

It is well-known that the damages to the environment are not restricted to one country. Wrong environmental policies have effects not only in neighboring countries, but on the entire world. So, this is not a question which can be treated exclusively on the internal level, it is really a global issue.

Regarding individuals or citizens' behavior, there is also a long way to go before people significantly modify their environmental attitudes. There have been some accomplishments in the last decade. A growing number of cities and citizens are more conscientious of the necessity to recycle garbage, to economize water, electricity and to adopt a more sustainable way of life in general. But, this is still insufficient to significantly reduce the greenhouse gas emissions and deter the environmental degradation. In my view, the public authorities are responsible for making sound environmental policies and to enforce - directly by means of pecuniary penalties or indirectly by means of tax incentives and other noneconomic measures - a more sustainable behavior by citizens.

\section{Ethical concerns}

So-called environmental ethics is a recent field. I'm not sure it can be really separated from Bioethics. Even so, we can defend, in this paper, that there are a lot of things that can be drawn from this title. We can define Environmental Ethics as: The set of ethical concerns 
which deals directly or indirectly with environmental issues such as: climate change, greenhouse gas emissions, drowning, floods, famine, and migration, among others. ${ }^{1}$

Notwithstanding, as it is part of the global field of Ethics, this definition is not sufficient, for there still remains the question: from which particular ethical point of view are we talking when we speak of environmental ethics? In other words, we cannot elude the question about our ethical position: are we Aristotelian, are we Kantian, are we Utilitarian? We must precise, when we talk about environmental issues, from which ethical point of view are we talking.

As Alasdair MacIntyre once said (MacIntyre 2007), our ethical position is the initial asset we have to enter the moral debate. It is important to begin with an ethical position. Otherwise, we will be inclined to assume an eclectic position, being subjected to the influence of the last argument.

So, even when we face a global threat such as climate change, or famine, or drowning, and so on, we can't escape the issue of our moral compromising, or our ethical initial position. In this paper, I begin from a Kantian position, evolving in the direction of a more contemporary ethics which can be related to some of the positions of Discursive Ethics as sketched mainly by Apel (1997) and Habermas (2003, 2004 and 2007).

As a matter of fact, Habermas' contributions to the environmental debate are rather limited. In his book, The Future of Human Nature (2003), he deals with questions of Bioethics like: the "good life", human dignity, species, nativity and eugenics. So, there are no direct questions about our relation with Nature, the environment, or climate change. However, we can find some interesting developments about the character of contemporary ethics, in a post-metaphysical age. We are no longer in the domain of normative ethics, or subjective ethics. The ethical behavior is more than interpersonal, trans-subjective. In this sense, Habermas shows that the intersubjective character of language precedes the individual. In his words: "The logos of language embodies the power of the intersubjective, which precedes and grounds the subjectivity of the speakers" (Habermas 2003, p. 11). This means, in the present context, that the question of responsibility for environment is more of a collective character than of an individual or subjective character.

Perhaps, Apel's work, Diskurs und Verantwortung, is more central to our discussion. The concept of responsibility is more akin to a reflection on the future of human nature 
related to the environmental questions. Of course, when one talks of responsibility, it is Hans Jonas' Principle of Responsibility (Jonas 2006; Bourg 1993) that comes to mind.

Indeed, Hans Jonas's The Principle of Responsibility, published in 1979, was probably one of the first books which treated the subject of the degradation of nature and the problems of environmental ethics as a major theme of philosophical reflection. It was preceded, by four years, by Peter Singer's Animal Liberation, which, however, treated more specifically the issue of non-human animals, and not of nature in general. There was also, on a level of (good) vulgarization, Fritjof Capra's The Tao of Physics (1975, 1983). Notwithstanding, Hans Jonas's book was far more systematic than the other works, and contributed to give to environmental ethics a solid philosophical status.

The first words of The principle of responsibility go straight to the core of our present concerns:

The Prometheus definitely unchained, to which science confers powers previously not thinkable and economy the restless impulse, claims for an ethics which, by means of voluntary restraints, block the power of men to be transformed in a disgrace for themselves. (Jonas 2016, p. 21). ${ }^{4}$

For the first time, people have effectively the power to destroy not only other people, but the entire planet. And Jonas was not referring only to nuclear power of mass destruction, but to the degradation of nature provoked by the action of mankind. It is more comprehensive than the egoistic concern with our own species, or our own generation: the concern is now with the next generations, other species and the future of life on Earth! So, I think we can consider Jonas's book as paradigmatic concerning environmental ethics. We can paraphrase Robert Nozick's saying: Environmental ethicists must either work within Hans Jonas' theory or explain why not. ${ }^{5}$

Although the question of irreversibility is still under consideration, I prefer now to work with Principle Responsibility, which includes hope and fear. There are some things that are truly irreversible, as the extinction of species, some radical transformations of nature given climate change, and so on. The longer we delay to take into account the reality of climate change (see Meadows, Randers \& Meadows 2012), the higher the threats facing some species, including human, flora and fauna alike. Even so, I think that it is never too late to change our habits, as individuals and institutions, and some of the diversity of nature can still be saved. 
The Principle of Responsibility at the same time differentiates itself from the Principle of Hope (Bloch 2005 [1959]) and of fear, and includes both. Says Hans Jonas: "Against the principle hope, we pose the principle of responsibility, and not the principle fear" (Jonas 2006, p. 351). But, he continues, "the fear belongs to responsibility, as much as fear" (Jonas 2006, p. 351).

Regarding the relation between man and nature, Jonas is very adamant: "The violation of nature and human civilization walks in the same pace" (Jonas 2006, p. 32). But now, we can argue, this degradation is exponential (Meadows, Randers \& Meadows 2012, p. 53 et passim). The thesis of Jonas is that the traditional ethics can no longer respond to the development of technique and to the means of destruction which are at the range of men. "The modern technique introduced actions of such magnitude, with such new objects and consequences, that the frame of ancient ethics can't contain it anymore" (Jonas 2006, p. 39), and he adds: "Nature as a human responsibility is certainly a novum which demands the thinking of a new ethical theory" (Jonas 2006, p. 39).

So, the question of irreversibility, the global dimension of climate change, the future not only of human nature, but of many species, and the intergenerational point of view, all points to the necessity of a new ethic. In Jonas's words:

\footnotetext{
No previous ethic has been obliged to consider the global condition of human life and the distant future, including the survival of the species. The fact that now this is in risk demands, in synthesis, a new conception of rights and duties, for which no ancient ethics and metaphysics can even offer the principles, still less a full doctrine (Jonas 2006, p. 41).
}

However, I would like to say something about Kantian ethics, which, in my view, can offer a basis for reflection on environmental issues. In particular, I refer to the following formulation of Kant's Categorical Imperative: "Act so that the maxim of your action, by means of your will, be a general law of nature" (Kant 1977 [1785], BA 52). ${ }^{6}$ In my view, this formulation can be used to think, more generally, on the environmental issues with which we are presently confronted.

Still, there is the question, above mentioned, that the people can't be forced to act autonomously, i.e., morally, otherwise, it would not be a genuinely autonomous action. As Habermas says:

Kant may be very good at explaining how to ground and apply moral norms, but he still are unable to answer the question of why we should be moral at all. (Habermas 2003, p. 4). 
But the stakes are so high in the environmental debate which we face today, that it is a matter of global survival. It is not a matter of choice; it is a duty regarding ourselves, future generations and the future of other forms of life on our planet. We can't be indifferent to that!

Still, there are some critical considerations that must be made to Hans Jonas's work, and I think that here Apel is the better guide. In his Diskurs und Verantwortung (Apel 1990, 2007), he agrees with Jonas concerning the centrality of environmental issues to philosophical reflection today. According to Apel,

the World's nr. 1 Problem in our time doesn't consist, exclusively, in finding a solution for the social conflicts between human beings inside the State or among States; it consists rather in finding also, at the same time, with the solution of social conflicts, the solution of the new type of conflict between human being as a whole and nature. (Apel 1990, p. 181; 2007, p. 133 [My translation]).

Notwithstanding, Apel points to a kind of conservatism in Jonas's position, and he distinguishes between two kinds of conservatism: there would be, following E. Eppler (1981), the "Wertkonservativen" (i.e., the "value conservative persons") and the "Strukturkonservativen" (i.e, the "structure conservative persons"). Jonas's would be a conservative of the first kind, but not of the second. (Apel 1990, pp. 186-187; 2007, p. 137).

If I fully understand Apel criticism here, I tend to agree with him. We can't be against technology, as a formal and abstract entity, but only against its utilization against the interests both of mankind and of life on Earth. Technology, itself, is a neutral tool. It can be used both to destroy and preserve Biosphere. So, Jonas would be conservative, in a sense that we could not agree, if he spoke against technology as such. I'm not sure that he truly defends that position, but I will here follow Apel, for the sake of argumentation.

It is interesting to note, in the contemporary debate on climate change, that some scientists also defend some sort of proactive intervention in the nature. In their view, we can't only wait, passively, that the predictable consequences of climate changes, as the elevation of Ocean temperature, the dissolution of coral reefs, the disappearing of some marine species, occur (or not). There must be more researches proposing interventions, on a local and regional scale, that effectively try to save some species and biological environments, instead of wait for global measures that can be too late, or never, implemented. Raw, Mcleod and HoeghGuldberg (2012), ${ }^{7}$ for instance, say: “(...) it is unwise to assume that we will be able to stabilize atmospheric $\mathrm{CO}_{2}$ at levels necessary to reduce or prevent ongoing damage to marine ecosystems" (p. 1).

They further add: 
Once $\mathrm{CO}_{2}$ - induced temperature and acid tolerance thresholds for a given species are crossed, there can be no quick return to tolerable conditions, barring active environmental intervention. In the case of ocean chemistry, the time frame for return to previous conditions is measured in many thousands of years. (Rau, McLeod \& Hoegh-Guldberg 2012, p. 2). ${ }^{8}$

So, the question of irreversibility, that I once considered (Rouanet 2005), must be reframed. The irreversibility can be not absolute, but it is still a threat. Even if it the degradation can be reverted, it can be irreversible for the present, and the next generations.

Returning to Apel, it must be said, also, that he seems, initially, still restrained to an ethic that is exclusively human. It is exemplar of this position the following quote:

It is not sufficient (...) when we declare the "permanence of authentic life on Earth" or the "continuation of mankind on Earth" as objective (quasi-ontological) of an ethics of responsibility. We also have to do justice to claims of justice, of effective and potentially expected claims of justice of all human beings living now and later. (Apel 1990, p. 196; 2007, p. 145).

On the contrary, today we face a reality, which is the reality of global climate change, which affects both human species and all the other species in the planet, and I think that Jonas is right in not considering sufficient the present models of ethics to deal with the present challenges, which menace the life on Earth, as a whole. In this sense, it must be considered not only human interest of the present generation and next generations, as also the interests of these who can't speak on their own behalf, as Apel also recognizes.

In short, Apel admits, with Jonas, that we arrived at an impasse regarding the "final foundation" of ethics:

We reach here the point of impasse of Modern philosophy face the problem of final foundation. And I believe, in accordance with Hans Jonas, that we can assert that the paradoxical character of this situation lies in the following circumstance: the same rationalscientific thought that affords technique, and in this manner presents the external challenge of an ethics of responsibility - the same thought seems to demonstrate, as objectification of the world value-free, to be impossible a rational foundation of ethical norms. (Apel 1990, p. 200; 2007, p. 148; italics by Apel).

Apel indeed takes seriously the Jonas's call for a new ethics, and he thinks Discourse Ethics can provide such an ethics. In his words, "in serious thought we already recognize a discourse ethics, or responsibility ethics in the sense of the universalized reciprocity of a community of communication potentially unlimited." (Apel 1981, p. 201; 2007, p. 149). And 
finally, he also recognizes that the responsibility also stands to "the possible problems of those that are not capable of speech" (Apel 1981, p. 202; 2007, p. 150).

So, we can assume that Apel agrees with Jonas, in his major thesis, and that he thinks that Discourse Ethics can provide an alternative to developing the new ethics called by Jonas.

\section{What can we do?}

Now that we actually know that environmental degradation is real, that climate change is occurring, we must face the problem. There is indeed the problem of irreversibility. Have we reached the point of "no return"? Probably, it's too late for many species, or kinds of vegetation, but we can't take it absolutely. If we do so, then fear will win, and hope, die. The principle of responsibility, precisely, stands between both, or goes further. On one side, there is the reality of environmental degradation, the extinction of species and kind of vegetation, the loss of landscapes like Kilimanjaro's "eternal snow", the melting of polar bank, and so on. But, on the other side, there is a lot of things that we can do, a lot of species which can be saved, including our own.

So, today I decided to put aside the question of irreversibility, preferring to focus, instead, in the Principle of Responsibility. John Rawls once said: "Political philosophy is realistically utopian when it extends what are ordinarily thought of as the limits of the practical political possibility" (Rawls 1999, p. 6). I think that environmental ethics is also a kind of political philosophy. It concerns the future not only of mankind, but of life as we now understand it, including other species and vegetation.

Of course, a lot of work has been done since 1979, when Hans Jonas first published his book, in Germany. The task, now, is to review this material, including Apel's contributions (Apel 1990), as we started to do above, in order to reach the state of the art regarding the notion of responsibility. In the second place, we must put it together to reflect upon our present world, its real condition and what we can do for it, and for us. There are now a lot of organizations around the world preoccupied with saving species, climate change and its consequences, the non-sustainable way of life of people and countries. One of the pioneers was Greenpeace, but there are others.

The participation in traditional politics, by means of Green Parties, has some limits. As politics, as traditionally understood, is an art of negotiation, it is difficult, for one thing, to trade with the future of life. So, now there is in Brazil a project that defends "zero 
deforestation" "It is a public petition that aims to collect 1,4 million signatures, to make deforestation illegal from now on.

The pre-salt oil exploration in Brazil is listed as one of the "World's biggest dirty energy projects" (Greenpeace 2013). Actually, it occupies the $9^{\text {th }}$ position in this ranking, out of 14. It combines high monetary investments, high technical risks and a huge emission of Greenhouse gas. It has been implemented by the government mostly for political reasons. Of course, it is a rather controversial issue, and we can here only express our concern. If we speak of "possible scenarios", then this seems a very bad one, in my opinion.

\section{Concluding remarks}

I spoke formerly of irreversibility, when referring to environmental ethics (Rouanet 2005). Now, I prefer to speak in terms of responsibility. It's an open question if we can take the Principle of Responsibility such as first formulated by Hans Jonas, or if we must take in account the many developments since then both by commentators and by other authors over the notion of responsibility. Probably, we must do both things: begin with Jonas' Principle of Responsibility and reach the state of the art over the notion of responsibility.

Certainly, this kind of research can't be executed alone. More than ever, research in the field of Philosophy, and specifically in Environmental Ethics, is a multi- and interdisciplinary area of research. Philosophy can give a general account of the main questions involved in the relation between man and nature nowadays and in the past, but it must be accompanied by its fellow research fields, like: History, Law, Archeology (why not?), Political Science, Biology, Astronomy, Literature (again, why not?) and many others. Only in this way can Philosophy fulfill its universal mission, that is, to be the "friend of wisdom". The acknowledgement of its intrinsic limitation gives to it the necessary humility that favors the "craving for knowledge". 


\section{Notas:}

${ }^{1}$ Professor Adjunto II do Departamento de Filosofia e Métodos da Universidade Federal de São João del Rei (UFSJ). Professor colaborador no Programa de Pós-Graduação em História da UFSJ. São João Del Rei, MG. Brasil. e-mail: luizrouanet@terra.com.br

2 http://wwf.panda.org/about_our_earth/aboutcc/problems/rising temperatures/hotspot_map/brazil.cfm , access in April 17, 2013.

${ }^{3}$ I'm aware of some criticisms that have been made to IPCC. According to these, the IPCC would "exaggerate" the data, viewing to receive more support for its own researches. I can't assess, here, these criticisms.

${ }^{4}$ My translation from Portuguese.

${ }^{5}$ The original sentence is: "Political philosophers now must either work within Rawls' theory or explain why not" (Nozick 1974, p. 183).

6 “ (...) handle so, als ob die Maxime deiner Handlung durch deinen Willen zu allgemeinen Naturgesetze werden solte".

${ }^{7}$ I thanks here to Bárbara Dutra, student of the Program of Post-Graduation in Sustainable Development of UFSJ, at Ouro Branco - MG, who kindly send me these indication.

${ }^{8}$ For some data regarding past eras and the relation between global warming and climate changes in the ocean, see Hönisch, Ridgwell et al., 2012. I'm also grateful to Bárbara Dutra for this indication.

${ }^{9}$ See http://desmatamentozero.org.br/. See also: http://www.greenpeace.org/brasil. Access in April 24, 2013. Especificamente, ver a sugestão de projeto de lei: http://www.desmatamentozero.org.br/pdf/pldesmatamentozero.pdf. 


\section{Bibliographical references:}

Apel, Karl-Otto. 1990. Diskurs und Verantwortung. Frankfurt: Suhrkamp.

Apel, Karl-Otto. 2007. Ética e responsabilidade. Trad. Jorge Telles Menezes. Lisboa : Instituto Piaget, 2007.

Bourg, Dominique. 1993. Hans Jonas et l'écologie. La Recherche, Paris: s.n, 24, n.256, p. 886-890, jul./ago.

Capra, F. 1983. O Tao da Física. 10ª ed. Trans. José Fernandes Dias. São Paulo: Cultrix.

Epler, E. 1981. Wege aus der Gefahr, Reunbeck.

Voorhar, Ria., and Myllyvirta, Lauri. 2013. Point of no return - The massive climate threats we must avoid. The Netherlands, Greenpeace International. http://www.greenpeace.org/international/Global/international/publications/climate/2013/Point OfNoReturn.pdf

Habermas, J. 2007. Ética da discussão e a questão da verdade. $2^{\mathrm{a}}$. ed. São Paulo: Martins Fontes.

Habermas, J. 2004. O futuro da natureza humana. São Paulo.

Habermas, J. 2003. The future of human nature. Polity Press.

Hönisch, Bärbel, Ridgwell, Andy et al. 2012. "The geological record of ocean acidification". Science 335: 1058-1063. doi: 10.1126/science.1208277

Jonas, Hans. 2006. O princípio responsabilidade. Rio de Janeiro: Contraponto.

Kant, Immanuel. 1977 [1785]. "Grundlegung zur Metaphysyk der Sitten”, in Werkausgabe, XII Banden. Bd. VII, Frankfurt a.M.: Suhrkamp.

MacIntyre, A. 2007. After Virtue - A Study in Moral Theory. $3^{\text {rd }}$. ed. Notre Dame Press.

Meadows, D.; Randers, J. \& Meadows, D. 2012. Los límites del crecimiento [Limits to Growth: The 30-Year Update). Transl. Sergio Pawlowski. Buenos Aires: Aguilar.

Nozick, Robert. 1974. Anarchy, State, and Utopia. New York: Basic Books.

Pascal, Georges. 1963. Oeuvres complètes. Paris: Du Seuil.

Rau, Greg H.; McLeod, Elizabeth L. ; Hoegh-Guldberg, Ove. 2012. "The need for new ocean conservation strategies in a high-carbon dioxide world". Nature Climate Change 2, 720-724.. doi:10.1038/nclimate1555 
Singer, Peter. 2009. Animal Liberation. Revised edition. New York: Harper Collins.

Rawls, John. 1999. Law of people. New York: Harvard University Press.

Rouanet, Luiz P. Ética ambiental e irreversibilidade. In: IV Simpósio Internacional Principia, 2005, Florianópolis. Ética: anais do IV Simpósio Internacional Principia: parte 2. Florianópolis: UFSC - Núcleo de Epistemologia e Lógica, 2005. v. 2. p. 143-155.

http://wwf.panda.org/about our earth/aboutcc/problems/rising temperatures/hotspot map/br azil.cfm, access in April 17, 2013.

http://desmatamentozero.org.br/, access in April 24, 2013.

http://www.greenpeace.org/brasil, access in April 24, 2013. 